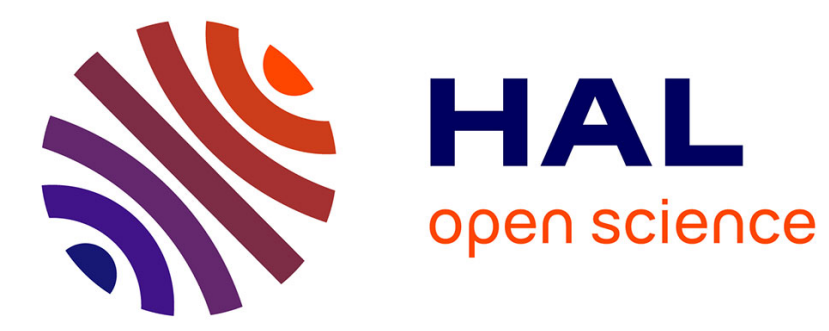

\title{
Fluorination of perovskite-related phases of composition LaSrFeCoO
}

Frank J. Berry, Xiaolin Ren, Richard Heap, Peter Slater, Michael F. Thomas

\section{To cite this version:}

Frank J. Berry, Xiaolin Ren, Richard Heap, Peter Slater, Michael F. Thomas. Fluorination of perovskite-related phases of composition LaSrFeCoO. Journal of Physics and Chemistry of Solids, 2009, 69 (8), pp.2032. 10.1016/j.jpcs.2008.02.018 . hal-00540539

\section{HAL Id: hal-00540539 \\ https://hal.science/hal-00540539}

Submitted on 27 Nov 2010

HAL is a multi-disciplinary open access archive for the deposit and dissemination of scientific research documents, whether they are published or not. The documents may come from teaching and research institutions in France or abroad, or from public or private research centers.
L'archive ouverte pluridisciplinaire HAL, est destinée au dépôt et à la diffusion de documents scientifiques de niveau recherche, publiés ou non, émanant des établissements d'enseignement et de recherche français ou étrangers, des laboratoires publics ou privés. 


\section{Author's Accepted Manuscript}

Fluorination of perovskite-related phases of composition $\mathrm{La}_{1-\mathrm{x}} \mathrm{Sr}_{\mathrm{x}} \mathrm{Fe}_{1-\mathrm{y}} \mathrm{Co}_{\mathrm{y}} \mathrm{O}_{3-\delta}$

Frank J. Berry, Xiaolin Ren, Richard Heap, Peter Slater, Michael F. Thomas

PII:

S0022-3697(08)00059-0

DOI: doi:10.1016/j.jpcs.2008.02.018

Reference: $\quad$ PCS 5398

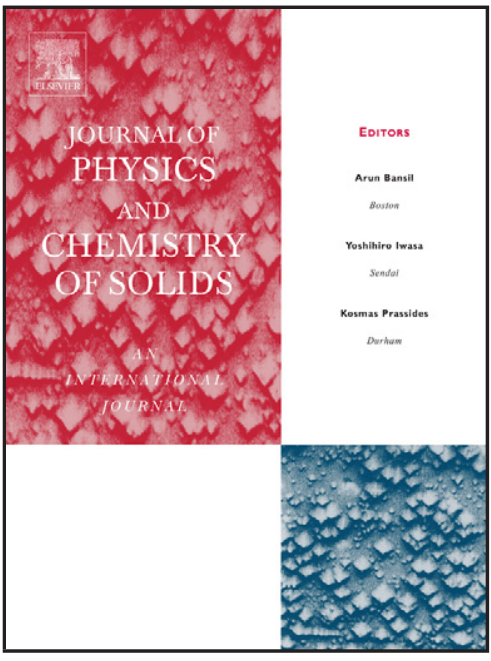

www.elsevier.com/locate/jpcs

To appear in: Journal of Physics and Chemistry of Solids

Received date: $\quad 18$ September 2007

Revised date: $\quad 19$ February 2008

Accepted date: $\quad 20$ February 2008

Cite this article as: Frank J. Berry, Xiaolin Ren, Richard Heap, Peter Slater and Michael F. Thomas, Fluorination of perovskite-related phases of composition $\mathrm{La}_{1-\mathrm{x}} \mathrm{Sr}_{\mathrm{x}} \mathrm{Fe}_{1-\mathrm{y}} \mathrm{Co}_{\mathrm{y}} \mathrm{O}_{3-\delta}$, Journal of Physics and Chemistry of Solids (2008), doi:10.1016/j.jpcs.2008.02.018

This is a PDF file of an unedited manuscript that has been accepted for publication. As a service to our customers we are providing this early version of the manuscript. The manuscript will undergo copyediting, typesetting, and review of the resulting galley proof before it is published in its final citable form. Please note that during the production process errors may be discovered which could affect the content, and all legal disclaimers that apply to the journal pertain. 


\author{
Proofs to: Professor F.J. Berry \\ Department of Chemistry \\ The Open University \\ Walton Hall \\ Milton Keynes MK7 6AA \\ United Kingdom
}

\title{
Fluorination of perovskite-related phases of composition
}

$$
\mathrm{La}_{1-\mathrm{x}} \mathrm{Sr}_{\mathrm{x}} \mathrm{Fe}_{1-\mathrm{y}} \mathrm{Co}_{\mathrm{y}} \mathrm{O}_{3-\delta}
$$

Frank J Berry ${ }^{\mathrm{a} *}$, Xiaolin Ren ${ }^{\mathrm{a}}$, Richard Heap ${ }^{\mathrm{b}}$ Peter Slater ${ }^{\mathrm{b}}$ and Michael F Thomas $^{\circ}$

${ }^{a}$ Department of Chemistry, The Open University, Walton Hall, Milton Keynes MK7 6AA, United Kingdom

${ }^{b}$ Chemistry, SBMS, University of Surrey, Guildford, Surrey, GU2 7XH, United Kingdom

${ }^{\circ}$ Department of Physics, University of Liverpool, Liverpool, L69 3BX, United Kingdom

* Corresponding author. E-mail address: f.j.berry@open.ac.uk 


\section{Abstract}

We report here on the fluorination of the perovskite-related phases $\mathrm{La}_{1-x} \mathrm{Sr}_{x} \mathrm{Fe}_{1-\mathrm{y}} \mathrm{Co}_{\mathrm{y}} \mathrm{O}_{3-\delta}$. The introduction of fluorine in place of oxygen is achieved through a low temperature $\left(400^{\circ} \mathrm{C}\right)$ reaction with poly(vinylidene fluoride). X-ray powder diffraction data show that in all cases the fluorination leads to an expansion in the unit cell which is consistent with partial replacement of oxygen by fluorine and consequent reduction in the oxidation state of iron and /or cobalt. This reduction in oxidation state is confirmed by X-ray absorption- and Mössbauer- spectroscopy. The Mössbauer spectra show complex magnetically split hyperfine patterns for the fluorinated samples, reflecting the interactions between $\mathrm{Fe}^{3+}$ ions which are not possible in oxides containing $\mathrm{Fe}^{4+}$.

Keywords: Oxide fluorides; Magnetic properties 


\section{Introduction}

The structural properties of oxygen deficient phases of the type $\mathrm{La}_{1-x} \mathrm{Sr}_{x} \mathrm{FeO}_{3-\delta}$ have attracted attention over the past half century because of the complex phase changes from orthorhombic at low values of $x$ through rhombohedral to cubic as the stoichiometry approaches $\mathrm{SrFeO}_{3}[1]$.

In more recent years the preparation and characterisation of inorganic oxide fluorides with perovskite-related structures has attracted significant interest [2-24]. Much of this work has focused on cuprate systems, following the report of superconductivity at $46 \mathrm{~K}$ in $\mathrm{Sr}_{2} \mathrm{CuO}_{2} \mathrm{~F}_{2+x}$ [2]. In addition, the fluorination has been mainly achieved by low temperature fluorination routes which is due to the fact that the number of oxide fluorides that can be prepared by the standard high temperature solid state route is limited by the high stability of the simple fluoride starting materials. In terms of low temperature fluorination, a range of fluorinating agents have been employed including $\mathrm{F}_{2}$ gas, $\mathrm{NH}_{4} \mathrm{~F}, \mathrm{MF}_{2}(\mathrm{M}=\mathrm{Cu}, \mathrm{Ni}, \mathrm{Zn})$ and $\mathrm{XeF}_{2}$. More recently a new method has been identified which entails heating the precursor oxide with the polymer, poly(vinylidene fluoride) [24]. This method was used for the synthesis of $\mathrm{Ca}_{2} \mathrm{CuO}_{2} \mathrm{~F}_{2}$ and $\mathrm{Sr}_{2} \mathrm{TiO}_{3} \mathrm{~F}_{2}$ from $\mathrm{Ca}_{2} \mathrm{CuO}_{3}$ and $\mathrm{Sr}_{2} \mathrm{TiO}_{4}$ respectively, and was shown to produce high quality samples without significant $\mathrm{CaF}_{2} / \mathrm{SrF}_{2}$ impurities which were often formed by other low temperature fluorination methods [24]. The method has recently been extended to the fluorination of $\mathrm{SrFeO}_{3-\mathrm{x}}$ to give $\mathrm{SrFeO}_{2} \mathrm{~F}$, showing that in addition to 
$\mathrm{K}_{2} \mathrm{NiF}_{4}$ type materials, the method can also be readily applied to perovskite systems [25].

In this paper we extend this work to examine the fluorination of a range of perovskiterelated phases of composition $\mathrm{La}_{1-x} \mathrm{Sr}_{x} \mathrm{Fe}_{1-y} \mathrm{Co}_{y} \mathrm{O}_{3-\delta}$. We describe here the structural properties of these materials and the effects of fluorination on the cationic oxidation states and the magnetic properties.

\section{Experimental}

Compounds of composition $\mathrm{La}_{1-x} \mathrm{Sr}_{x} \mathrm{Fe}_{1-y} \mathrm{Co}_{y} \mathrm{O}_{3-\delta}$ were prepared by the calcination of appropriate quantities of well ground lanthanum(III) oxide, strontium(II) carbonate, iron (III) oxide and cobalt (II) oxide at $1250^{\circ} \mathrm{C}$ for 24 hours in air. Fluorination was achieved by mixing the $\mathrm{La}_{1-x} \mathrm{Sr}_{x} \mathrm{Fe}_{1-y} \mathrm{Co}_{y} \mathrm{O}_{3-\delta}$ phase with poly(vinylidene fluoride) in a 1:0.75 molar ratio (precursor oxide: $\mathrm{CH}_{2} \mathrm{CF}_{2}$ monomer unit) and heating the mixture at $400{ }^{\circ} \mathrm{C}$ for 24 hours in flowing nitrogen.

X-ray powder diffraction patterns were recorded with a Siemans D5000 diffractometer using $\mathrm{Cu}$ Ka radiation at 298K. Sr K-, LaII-, Fe K- and Co K-edge X-ray absorption spectra were recorded at the Synchrotron Radiation Source at Daresbury Laboratory UK with an average current of $200 \mathrm{~mA}$ at $2 \mathrm{GeV}$. The data were collected at $298 \mathrm{~K}$ in transmission geometry on Station 7.1 (La-, Fe- and Co-edge) and Station 9.2 (Sredge).The samples were examined as pressed discs. The position of the X-ray 
absorption edge was defined as the energy at which the normalised absorption was 0.5 , i.e., the absorption at half-height of the edge step.

The ${ }^{57} \mathrm{Fe}$ Mössbauer spectra were recorded at $298 \mathrm{~K}$ and $77 \mathrm{~K}$ with a constant acceleration spectrometer using a ca. $25 \mathrm{mCi} \mathrm{Co/Rh}$ source. The ${ }^{57} \mathrm{Fe}$ Mössbauer chemical isomer shift data are quoted relative to metallic iron at room temperature.

\section{Results and Discussions}

The X-ray powder diffraction patterns recorded from materials of composition $\mathrm{La}_{1-\mathrm{x}} \mathrm{Sr}_{x} \mathrm{Fe}_{1-y} \mathrm{Co}_{y} \mathrm{O}_{3-\delta}$ and their fluorinated derivatives are shown in Figure 1. The patterns show that fluorination induces a shift in peak position to lower angles

Figure 1 about here

corresponding to an increase in unit cell size. Heating the samples subsequently in air at $400^{\circ} \mathrm{C}$ resulted in no further changes, consistent with the partial replacement of oxygen by fluorine rather than a simple reduction in oxygen content.

The lattice parameters recorded from the pure oxides and their fluorinated derivatives are collected in Table 1. From the data in Table 1 it can be seen that if the primitive perovskite subcells for each sample are compared, the fluorination leads to a significant increase in cell parameters. This is consistent with the 
Table 1 about here

partial replacement of $\mathrm{O}^{2-}$ by $\mathrm{F}^{-}$leading to a reduction in the transition metal oxidation state and consequently longer bond distances and a larger unit cell.

The X-ray absorption edge data recorded from materials of the type $\mathrm{La}_{1-\mathrm{x}} \mathrm{Sr}_{x} \mathrm{Fe}_{1-y} \mathrm{Co}_{y} \mathrm{O}_{3-\delta}$, their fluorinated derivatives and appropriate standards are collected in Table 2. The La $\mathrm{L}_{\text {III- }}$ and Sr K- X-ray absorption edge positions of all the materials did not change upon fluorination and were all characteristic of $\mathrm{La}^{3+}$ and $\mathrm{Sr}^{2+}$ in compounds of the type $\mathrm{La}_{1-}$ ${ }_{x} \mathrm{Sr}_{x} \mathrm{Fe}_{1-y} \mathrm{Co}_{y} \mathrm{O}_{3-\delta}$ and confirm that fluorination

\section{Table 2 about here}

has little influence on the rare earth or alkaline earth element. The Fe K-edge X-ray absorption positions in all the pure oxides were similar to those of $\mathrm{Fe}^{4+}$ in $\mathrm{SrFeO}_{3-\delta}$ and moved to a lower energy characteristic of $\mathrm{Fe}^{3+}$ upon fluorination indicative of a decrease in the oxidation state of iron. In the compound $\mathrm{La}_{0.1} \mathrm{Sr}_{0.9} \mathrm{Fe}_{0.5} \mathrm{Co}_{0.5} \mathrm{O}_{3-\delta}$ the $\mathrm{Co}^{3+}$ edge positions showed a small shift to lower energy upon fluorination. Hence the results indicate that fluorination of materials of the type $\mathrm{La}_{1-x} \mathrm{Sr}_{x} \mathrm{Fe}_{1-y} \mathrm{Co}_{y} \mathrm{O}_{3-\delta}$ is accompanied by reduction of the transition element ions and is consistent with the increase in unit cell parameters as a result of, for example, the larger size of $\mathrm{Fe}^{3+}$ (ca. $0.64 \AA$ ) as compared to $\mathrm{Fe}^{4+}($ ca. $0.58 \AA)$ [26]. 
The ${ }^{57} \mathrm{Fe}$ Mössbauer spectra recorded from $\mathrm{SrFeO}_{3-\delta}, \mathrm{La}_{0.1} \mathrm{Sr}_{0.9} \mathrm{FeO}_{3-\delta}, \mathrm{La}_{0.1} \mathrm{Sr}_{0.9}$ $\mathrm{Fe}_{0.5} \mathrm{Co}_{0.5} \mathrm{O}_{3-\delta}$ and their fluorinated derivatives are illustrated in Figures 2, 3 and 4 respectively. The ${ }^{57} \mathrm{Fe}$ Mössbauer parameters are collected in Table 3.

Figures 2, 3 and 4 about here

Table 3 about here

\section{$\mathrm{SrFeO}_{3-\delta}$}

The spectrum recorded at $300 \mathrm{~K}$ was best fitted to a doublet $\left(\delta=c a .0 .04 \mathrm{mms}^{-1}, \Delta=c a\right.$. $0.12 \mathrm{mms}^{-1}$ ) characteristic of $\mathrm{Fe}^{4+}$ together with a further doublet with a slightly higher chemical isomer shift $\left(\delta=c a .0 .14 \mathrm{mms}^{-1}, \Delta=c a .0 .69 \mathrm{mms}^{-1}\right)$. The chemical isomer shift of the latter is intermediate between that characteristic of an $\mathrm{Fe}^{3+}$ species $(\delta=c a$. $\left.0.35 \mathrm{mms}^{-1}\right)$ and an $\mathrm{Fe}^{4+}$ species $(\delta=c a .0 .04 \mathrm{mms}-1)$ and is indicative of an ion of mean charge. Such a description may imply charge sharing between neighbouring $\mathrm{Fe}^{3+}$ and $\mathrm{Fe}^{4+}$ ions with a timescale smaller than $10^{-8}$ seconds. The results are very similar to those previously [27] recorded from the oxygen deficient variant of $\mathrm{Fe}^{4+}$-containing $\mathrm{SrFeO}_{3-\delta}$. The spectrum also contained a quadrupole split absorption $\left(\delta=c a .0 .35 \mathrm{mms}^{-}\right.$ ${ }^{1}, \Delta=$ ca. $1.26 \mathrm{mms}^{-1}$ ) characteristic of an $\mathrm{Fe}^{3+}$-containing impurity phase. Ignoring the $\mathrm{Fe}^{3+}$-containing impurity component, the two contributions comprising the $\mathrm{Fe}^{4+}$ - 
containing components constitute an $\mathrm{Fe}^{4+}$ nature of $77 \%$ (all of component at $\delta=0.04 \mathrm{mms}^{-1}$ and half of component at $\delta=0.14 \mathrm{mms}^{-1}$ ) leading to a calculated formula of $\mathrm{SrFeO}_{2.88}$ for $\mathrm{SrFeO}_{3-\delta}$ The spectrum recorded at $77 \mathrm{~K}$ showed a doublet $(\delta=c a .0 .04$ $\left.\mathrm{mms}^{-1}, \Delta=c a .0 .26 \mathrm{mms}^{-1}\right)$ characteristic of $\mathrm{Fe}^{4+}$ with two sextet patterns, one $(\delta=c a$. $0.27 \mathrm{mms}^{-1}, 2 \varepsilon=c a$. $-0.68 \mathrm{mms}^{-1}, H=3.4 \mathrm{~T}$ ) characteristic of charge sharing between the $\mathrm{Fe}^{4+}$ and $\mathrm{Fe}^{3+}$ ions and the other, $\left(\delta=c a .0 .47 \mathrm{mms}^{-1}, 2 \varepsilon=c a .-1.33 \mathrm{mms}^{-1}, H=\right.$ 43.6 T) characteristic of the $\mathrm{Fe}^{3+}$ containing impurity phase, which was not visible in the $\mathrm{XRD}$ pattern, and so is presumed to be due to an amorphous impurity. The slightly more positive chemical isomer shifts recorded at $77 \mathrm{~K}$ are consistent with the contribution resulting from the second order Doppler shift at the lower temperature.

The spectrum recorded at $300 \mathrm{~K}$ from the fluorinated derivative was best fitted to the superposition of two sextet patterns together with a profile which can be fitted to a hyperfine field of ca. $4.5 \mathrm{~T}$ but all with chemical isomer shifts characteristic of $\mathrm{Fe}^{3+}$. The spectrum recorded at $77 \mathrm{~K}$ was similar with the component of smallest hyperfine field appearing as a broadened singlet. The results are consistent with fluorination inducing the reduction of $\mathrm{Fe}^{4+}$ in the $\mathrm{SrFeO}_{3}$-related phase to $\mathrm{Fe}^{3+}$. The results endorse the evidence from XANES for fluorination inducing the reduction of $\mathrm{Fe}^{4+}$ to $\mathrm{Fe}^{3+}$. The predominance of complex magnetically split hyperfine patterns recorded from the fluorinated materials reflects the interaction between $\mathrm{Fe}^{3+}$ ions, which are not possible in oxides containing $\mathrm{Fe}^{4+}$. Given the presence of only $\mathrm{Fe}^{3+}$, the results suggest a formula of $\mathrm{SrFeO}{ }_{2} \mathrm{~F}$ for the fluorinated phase. 


\section{$\mathrm{La}_{0.1} \mathrm{Sr}_{0.9} \mathrm{FeO}_{3-\delta}$}

The ${ }^{57} \mathrm{Fe}$ Mössbauer spectrum recorded at $300 \mathrm{~K}$ was composed of a doublet $(\delta=-$ $\left.0.02 \mathrm{mms}^{-1}, \Delta=0.26 \mathrm{mms}^{-1}\right)$ characteristic of $\mathrm{Fe}^{4+}$ and another doublet $\left(\delta=0.28 \mathrm{mms}^{-}\right.$ ${ }^{1}, \Delta=0.54 \mathrm{mms}^{-1}$ ) characteristic of the presence of a mixed $\mathrm{Fe}^{4+} / \mathrm{Fe}^{3+}$ species. The oxygen deficiency of $\mathrm{La}_{0.1} \mathrm{Sr}_{0.9} \mathrm{FeO}_{3-}$ was calculated from the Mössbauer spectral components (Table 3) associating the $\mathrm{Fe}^{4+} / \mathrm{Fe}^{3+}$ component with charge sharing between neighbouring $\mathrm{Fe}^{4+}$ and $\mathrm{Fe}^{3+}$ ions (see above) and represented by a mixture of half $\mathrm{Fe}^{4+}$ and half $\mathrm{Fe}^{3+}$. Hence ca. $77 \%$ of the spectral area may be associated with $\mathrm{Fe}^{4+}$ giving a composition of $\mathrm{La}_{0.1} \mathrm{Sr}_{0.9} \mathrm{FeO}_{2.93}$. The spectrum recorded at $77 \mathrm{~K}$ showed two magnetically split components characteristic of $\mathrm{Fe}^{4+} / \mathrm{Fe}^{3+}$ and a broadened singlet component with an isomer shift characteristic of $\mathrm{Fe}^{4+}$. Fluorination gave a material from which the ${ }^{57} \mathrm{Fe}$ Mössbauer spectrum at $300 \mathrm{~K}$ showed three magnetically split components, one $\left(\delta=0.23 \mathrm{mms}^{-1}, 2 \varepsilon=0.60 \mathrm{mms}^{-1}, H=44 \mathrm{~T}\right)$ characteristic of a mixture of $\mathrm{Fe}^{3+}$ and $\mathrm{Fe}^{4+}$, whilst the other two sextet patterns corresponding to ca. $68 \%$ of the spectral area, were characteristic of $\mathrm{Fe}^{3+}$. The presence of of ca. $32 \%$ mixed $\mathrm{Fe}^{3+} / \mathrm{Fe}^{4+}$ indicates that the fluorination has not resulted in complete reduction to $\mathrm{Fe}^{3+}$ in this case. This may have been related to loss of the poly (vinylidene fluoride) on heating before the full fluorination had occurred.

The results demonstrate the reduction of $\mathrm{Fe}^{4+}$ to $\mathrm{Fe}^{3+}$ as a result of fluorination and the concomitant inducement of magnetic order. The spectrum recorded at $77 \mathrm{~K}$ was amenable to similar analysis. From an analysis of the spectral areas of the two 
components in the Mössbauer spectrum a composition of $\mathrm{La}_{0.1} \mathrm{Sr}_{0.9} \mathrm{FeO}_{2.26} \mathrm{~F}_{0.74}$ can be estimated.

\section{$\mathrm{La}_{0.1} \mathrm{Sr}_{0.9} \mathrm{Fe}_{0.5} \mathrm{Co}_{0.5} \mathrm{O}_{3-\delta}$}

The ${ }^{57} \mathrm{Fe}$ Mössbauer spectrum recorded from the compound $\mathrm{La}_{0.1} \mathrm{Sr}_{0.9} \mathrm{Fe}_{0.5} \mathrm{Co}_{0.5} \mathrm{O}_{3-\delta}$ at $300 \mathrm{~K}$ was composed of two doublets characteristic of mixed $\mathrm{Fe}^{4+}$ and $\mathrm{Fe}^{3+}$ species. At 77K the spectra showed a singlet and two magnetically split components. The oxygen deficiency of $\mathrm{La}_{0.1} \mathrm{Sr}_{0.9} \mathrm{Fe}_{0.5} \mathrm{Co}_{0.5} \mathrm{O}_{3-\delta}$ was calculated from the Mössbauer spectral area assuming $50 \% \mathrm{Fe}^{4+}$ and $50 \% \mathrm{Fe}^{3+}$ (Table 3 ) and cobalt being present as $\mathrm{Co}^{3+}$ (XANES) and a formulation $\mathrm{La}_{0.1} \mathrm{Sr}_{0.9} \mathrm{Fe}_{0.5} \mathrm{Co}_{0.5} \mathrm{O}_{2.68}$ estimated: Fluorination gave complex magnetically split spectra at $300 \mathrm{~K}$ and $77 \mathrm{~K}$ which both showed that more than ca. $90 \%$ of the iron was present in the $\mathrm{Fe}^{3+}$ state. From the Mössbauer spectral areas a formula $\mathrm{La}_{0.1} \mathrm{Sr}_{0.9} \mathrm{Fe}_{0.5} \mathrm{Co}_{0.5} \mathrm{O}_{2.12} \mathrm{~F}_{0.88}$ was estimated.

\section{Conclusions}

We have shown that the perovskite-related phases $\mathrm{La}_{1-x} \mathrm{Sr}_{x} \mathrm{Fe}_{1-y} \mathrm{Co}_{y} \mathrm{O}_{3-\delta}$ can be successfully fluorinated by low temperature reaction with poly(vinylidene fluoride). The method leads to the partial replacement of oxygen by fluorine and a consequent reduction in the oxidation state of the transition metal. The results imply that the method is a potentially powerful means for the controlling the oxidation states of transition metal compounds, and we will be investigating this feature in more detail, in particular by varying the ratio of precursor oxide to poly(vinylidene fluoride) in the fluorination 
reaction. Conventionally, such control of the transition metal oxidation state in perovskite-type materials has been achieved by cation doping (e.g. $\mathrm{La}_{1-x} \mathrm{Sr}_{x} \mathrm{FeO}_{3}$ ), while this fluorination route opens up the possibility of similar control through modifications on the anion site (e.g. $\mathrm{SrFeO}_{2+\mathrm{x}} \mathrm{F}_{1-\mathrm{x}}$ ). Mössbauer spectroscopy indicates that the fluorinated phases exhibit magnetic ordering above room temperature, and further studies by high temperature neutron diffraction are planned to study this feature in more detail. Further work is also required to determine the exact fluorine content. Use of a fluoride ion selective electrode has proved impractical due to solubility problems.

\section{Acknowledgements}

We thank EPSRC for a studentship to RH. We would also like to thank the SRS, Daresbury for the provision of beamtime. 


\section{References}

[1] S. E. Dann, D. B. Currie, M. T. Weller, M. F. Thomas, A. D. Al-Rawwas, J. Solid State Chem., 109 (1994) 134.

[2] M. Al-Mamouri, P.P. Edwards, C. Greaves, M. Slaski, Nature (London) 369 (1994) 382

[3] R.L. Needs, M.T. Weller, Chem. Comm. (1995) 353.

[4] R.L. Needs, M.T. Weller, Dalton Trans. (1995) 3015.

[5] R.L. Needs, M.T. Weller, U. Scheler, R.K. Harris, J. Mater. Chem. 6 (1996) 1219.

[6] R.L. Needs, M.T. Weller, J. Solid State Chem. 139 (1998) 422.

[7] T. Kawahima, Y. Matsui, E. Takayama-Muromachi; Physica C 257 (1996) 313.

[8] M. Isobe, J.Q. Li, Y. Matsui, F. Izumi, Y. Kanke, E. Takayama-Muromachi, Physica C 269 (1996) 5.

[9] P.R. Slater, P.P. Edwards, C. Greaves, I. Gameson, J.P. Hodges, M.G. Francesconi, M. Al-Mamouri, M. Slaski, Physica C 241 (1995) 151.

[10] P.R. Slater, J.P. Hodges, M.G. Francesconi, P.P. Edwards, C. Greaves, I.Gameson, M. Slaski, Physica C 253 (1995) 26

[11] E.I.Ardashnikova, S.V. Lubarsky, D.I. Denisenko, R.V. Shpanchenko, E.V. Antipov, G. Van Tendeloo, Physica C 253 (1995) 259. 
[12] P.Lightfoot, S. Pei, J.D. Jorgensen, X.X. Tang, A. Manthiram, J.B.Goodenough, Physica C 169 (1990) 15.

[13] J.L.Yang, J.K. Liang, G.H. Rao, Y.L. Qin, Y. Shi, W.H. Tang, Physica $\quad$ C 270 (1996) 35.

[14] P.R.Slater, J.P. Hodges, M.G. Francesconi, C. Greaves, and M. Slaski, J.Mater. Chem. 7 (1997) 2077.

[15] E.V.Antipov, S.N. Putilin, R.V. Shpanchenko, V.A. Alyoshin, M.G. Rozova, A.M. Abakumov, D.A. Mikhailova, A.M. Balagurov, O. Lebedev, G. Van Tendeloo, Physica C 282 (1997) 61.

[16] A.M. Abakumov, J. Hadermann, G. Van Tendeloo, R.V. Shpanchenko, P.N. Oleinikov, E.V. Antipov, J. Solid State Chem. 142 (1999) 440.

[17] G.B. Peacock, I. Gameson, M. Slaski, J.J. Capponi, and P.P. Edwards, Physica C 289 (1997) 153.

[18] C. Greaves, J.L. Kissick, M.G. Francesconi, L.D. Aiken, L.J. Gillie; J. Mater. Chem. 9 (1999) 111.

[19] G.S. Case, A.L. Hector, W. Levason, R.L. Needs, M.F. Thomas, M.T. Weller; J. Mater. Chem. 9 (1999) 2821.

[20] L.D. Aikens, R.K. Li, C. Greaves; Chem Commun. (2000) 2129.

[21] P.R. Slater, R.K.B. Gover; J. Mater. Chem. 11 (2001) 2035. 
[22] M. G. Francesconi, C. Greaves, Supercond. Sci. Techol., 10 (1997) A29

[23] C. Greaves and M. G. Francesconi, Current Opinion in Solid State and Materials Science 3 (1998) 132

[24] P. R. Slater, J. Fluorine Chem., 117 (2002) 43

[25] F.J. Berry, X. Ren, R. Heap, P.R. Slater, M.F. Thomas; Solid State Commun. 134 (2005) 621.

[26] R D Shannon, Acta Cryst., A32 (1976) 751,

[27] A. D. Al-Rawwas, PhD Thesis, University of Liverpool, 1994 
Legends to Figures

Figure $1 \quad$ X-ray powder diffraction patterns recorded from materials of composition $\mathrm{La}_{1-x} \mathrm{Sr}_{\mathrm{x}} \mathrm{Fe}_{1-\mathrm{y}} \mathrm{Co}_{y} \mathrm{O}_{3-\delta}$ and their fluorinated derivatives.

Figure $2 \quad{ }^{57} \mathrm{Fe}$ Mössbauer spectra recorded from $\mathrm{SrFeO}_{3-\delta}$ at $300 \mathrm{~K}$ and $77 \mathrm{~K}$ and following fluorination and recorded at $300 \mathrm{~K}$ and $77 \mathrm{~K}$.

Figure $3 \quad{ }^{57} \mathrm{Fe}$ Mössbauer spectra recorded from $\mathrm{La}_{0.1} \mathrm{Sr}_{0.9} \mathrm{FeO}_{3-\delta}$ at $300 \mathrm{~K}$ and $77 \mathrm{~K}$ and following fluorination and recorded at $300 \mathrm{~K}$ and $77 \mathrm{~K}$

Figure $4 \quad{ }^{57} \mathrm{Fe}$ Mössbauer spectra recorded from $\mathrm{La}_{0.1} \mathrm{Sr}_{0.9} \mathrm{Fe}_{0.5} \mathrm{Co}_{0.5} \mathrm{O}_{3-\delta}$ at $300 \mathrm{~K}$ and $77 \mathrm{~K}$ and following fluorination and recorded at $300 \mathrm{~K}$ and $77 \mathrm{~K}$. 
Table 1 Lattice parameters of materials of composition $\mathrm{La}_{1-\mathrm{x}} \mathrm{Sr}_{x} \mathrm{Fe}_{1-y} \mathrm{Co}_{y} \mathrm{O}_{3-\delta}$ and their fluorinated derivatives.

\begin{tabular}{|c|c|c|}
\hline Sample & lattice parameters $(\AA)$ & Primitive cell volume $\left(\AA^{3}\right)$ \\
\hline $\mathrm{SrFeO}_{3 . \delta}$ & $\begin{array}{l}\text { Orth, } a=5.474(1) b=5.469(1) \\
c=7.706(1)\end{array}$ & 57.6 \\
\hline $\mathrm{SrFeO}_{3 . \delta} / \mathrm{F}$ & Cubic, $a=3.956(1)$ & 61.9 \\
\hline $\mathrm{La}_{0.1} \mathrm{Sr}_{0.9} \mathrm{FeO}_{3 . \delta}$ & Cubic, $a=3.865(1)$ & 57.7 \\
\hline $\mathrm{La}_{0.1} \mathrm{Sr}_{0.9} \mathrm{FeO}_{3 . \delta} / \mathrm{F}$ & $\begin{array}{l}\text { Orth, } a=5.562(1) b=5.584(1) \\
c=7.904(1)\end{array}$ & 61.3 \\
\hline $\mathrm{La}_{0.1} \mathrm{Sr}_{0.9} \mathrm{Fe}_{0.5} \mathrm{Co}_{0.5} \mathrm{O}_{3 . \delta}$ & Cubic, $a=3.854(1)$ & 57.2 \\
\hline $\mathrm{La}_{0.1} \mathrm{Sr}_{0.9} \mathrm{Fe}_{0.5} \mathrm{Co}_{0.5} \mathrm{O}_{3 . \delta} / \mathrm{F}$ & Rhom, $a=5.582(1), c=13.626(2)$ & 61.2 \\
\hline
\end{tabular}


Table 2 X-ray Absorption Edge Positions Recorded from the X-ray Absorption Near Edge Structure

Edge Positions $(\mathrm{eV}) \pm 0.5$

\begin{tabular}{lcccc}
\hline & $\mathrm{Fe}$ & $\mathrm{Co}$ & $\mathrm{La}$ & $\mathrm{Sr}$ \\
\hline $\mathrm{LaFeO}_{3}$ & 7120.7 & & 5481.5 & \\
$\mathrm{LaCOO}_{3}$ & & 7717.9 & 5481.5 & \\
$\mathrm{SrFeO}_{3 . \delta}$ & 7121.0 & & & 16110.4 \\
$\mathrm{SrFeO}_{3 . \delta} / \mathrm{F}$ & 7119.7 & & 16110.4 \\
$\mathrm{La}_{0.1} \mathrm{Sr}_{0.9} \mathrm{FeO}_{3 . \delta}$ & 7121.2 & & 5481.2 & 16110.3 \\
$\mathrm{La}_{0.1} \mathrm{Sr}_{0.9} \mathrm{FeO}_{3 . \delta} / \mathrm{F}$ & 7119.9 & & 5481.2 & 16110.3 \\
$\mathrm{La}_{0.1} \mathrm{Sr}_{0.9} \mathrm{Fe}_{0.5} \mathrm{CO}_{0.5} \mathrm{O}_{3 . \delta}$ & 7121.4 & 7717.2 & 5481.7 & 16110.1 \\
$\mathrm{Laa}_{0.1} \mathrm{Sr}_{0.9} \mathrm{Fe}_{0.5} \mathrm{Co}_{0.5} \mathrm{O}_{3 . \delta} / \mathrm{F}$ & 7120.5 & 7716.4 & 5481.3 & 16110.3
\end{tabular}


Table $3{ }^{57} \mathrm{Fe}$ Mössbauer parameters recorded from materials of composition $\mathrm{La}_{1-\mathrm{x}} \mathrm{Sr}_{\mathrm{x}} \mathrm{Fe}_{1-\mathrm{y}} \mathrm{Co}_{\mathrm{y}} \mathrm{O}_{3-\delta}$ and their fluorinated derivatives

\begin{tabular}{|c|c|c|c|c|c|c|}
\hline Compound & $\begin{array}{c}\text { Temperature of } \\
\text { Measurement } \\
\mathrm{K}\end{array}$ & Assignment & $\begin{array}{l}\delta \pm 0.05 \\
/ \mathrm{mms}^{-1}\end{array}$ & $\begin{array}{c}\Delta \text { or } 2 \varepsilon \pm 0.10 \\
/ \mathrm{mms}^{-1}\end{array}$ & $\begin{array}{c}\mathrm{H} \pm 0.5 \\
/ \mathrm{T}\end{array}$ & $\begin{array}{c}\text { Area } \pm 5 \\
\%\end{array}$ \\
\hline \multirow{3}{*}{$\mathrm{SrFeO}_{3-\delta}$} & 300 & $\mathrm{Fe}^{4+}$ & 0.04 & 0.12 & 0 & 44 \\
\hline & & $\begin{array}{c}\mathrm{Fe}^{4+} / \mathrm{Fe}^{3+} \\
\mathrm{Fe}^{3+}\end{array}$ & $\begin{array}{l}0.14 \\
0.35\end{array}$ & $\begin{array}{l}0.69 \\
1.26\end{array}$ & $\begin{array}{l}0 \\
0\end{array}$ & $\begin{array}{l}38 \\
18\end{array}$ \\
\hline & 77 & $\begin{array}{c}\mathrm{Fe}^{4+} \\
\mathrm{Fe}^{4+} / \mathrm{Fe}^{3+} \\
\mathrm{Fe}^{3+}\end{array}$ & $\begin{array}{l}0.04 \\
0.27 \\
0.47\end{array}$ & $\begin{array}{l}0.26 \\
-0.68 \\
-1.33\end{array}$ & $\begin{array}{c}0 \\
3.4 \\
43.6\end{array}$ & $\begin{array}{l}47 \\
38 \\
15\end{array}$ \\
\hline \multirow[t]{3}{*}{$\mathrm{SrFeO}_{3-\delta} / \mathrm{F}$} & 300 & $\mathrm{Fe}^{3+}$ & 0.37 & -0.01 & 52.3 & 45 \\
\hline & & $\begin{array}{l}\mathrm{Fe}^{3+} \\
\mathrm{Fe}^{3+}\end{array}$ & $\begin{array}{l}0.37 \\
0.37\end{array}$ & $\begin{array}{l}-0.05 \\
-0.01\end{array}$ & $\begin{array}{c}50.1 \\
4.5\end{array}$ & $\begin{array}{l}45 \\
10\end{array}$ \\
\hline & 77 & $\begin{array}{l}\mathrm{Fe}^{3+} \\
\mathrm{Fe}^{3+} \\
\mathrm{Fe}^{3+}\end{array}$ & $\begin{array}{l}0.47 \\
0.46 \\
0.44\end{array}$ & $\begin{array}{c}0.01 \\
-0.09 \\
0.00\end{array}$ & $\begin{array}{c}56.1 \\
54.1 \\
1.8\end{array}$ & $\begin{array}{c}43 \\
49 \\
8\end{array}$ \\
\hline \multirow[t]{2}{*}{$\mathrm{La}_{0.1} \mathrm{Sr}_{0.9} \mathrm{FeO}_{3-\delta}$} & 300 & $\begin{array}{c}\mathrm{Fe}^{4+} \\
\mathrm{Fe}^{4+} / \mathrm{Fe}^{3+}\end{array}$ & $\begin{array}{l}-0.02 \\
028\end{array}$ & $\begin{array}{l}0.26 \\
0.54\end{array}$ & $\begin{array}{l}0 \\
0\end{array}$ & $\begin{array}{l}53 \\
47\end{array}$ \\
\hline & 77 & $\begin{array}{c}\mathrm{Fe}^{4+} \\
\mathrm{Fe}^{4+} / \mathrm{Fe}^{3+} \\
\mathrm{Fe}^{4+} / \mathrm{Fe}^{3+}\end{array}$ & $\begin{array}{l}0.05 \\
0.34 \\
0.40\end{array}$ & $\begin{array}{l}0.26 \\
0.35 \\
0.40\end{array}$ & $\begin{array}{c}2.0 \\
31.0 \\
38.2\end{array}$ & $\begin{array}{c}48 \\
47 \\
5\end{array}$ \\
\hline \multirow[t]{3}{*}{$\mathrm{La}_{0.1} \mathrm{Sr}_{0.9} \mathrm{FeO}_{3-\delta} / \mathrm{F}$} & 300 & $\mathrm{Fe}^{4+} / \mathrm{Fe}^{3+}$ & 0.23 & 0.60 & 44.0 & 32 \\
\hline & & $\begin{array}{l}\mathrm{Fe}^{3+} \\
\mathrm{Fe}^{3+}\end{array}$ & $\begin{array}{l}0.39 \\
0.35\end{array}$ & $\begin{array}{l}-0.39 \\
-0.40\end{array}$ & $\begin{array}{l}52.1 \\
49.4\end{array}$ & $\begin{array}{l}43 \\
25\end{array}$ \\
\hline & 77 & $\begin{array}{c}\mathrm{Fe}^{4+} / \mathrm{Fe}^{3+} \\
\mathrm{Fe}^{3+} \\
\mathrm{Fe}^{3+}\end{array}$ & $\begin{array}{l}0.31 \\
0.49 \\
0.44\end{array}$ & $\begin{array}{l}0.68 \\
-0.36 \\
-0.43\end{array}$ & $\begin{array}{l}46.9 \\
55.5 \\
53.1\end{array}$ & $\begin{array}{l}24 \\
46 \\
30\end{array}$ \\
\hline \multirow[t]{2}{*}{$\mathrm{La}_{0.1} \mathrm{Sr}_{0.9} \mathrm{Fe}_{0.5} \mathrm{Co}_{0.5} \mathrm{O}_{3-\delta}$} & 300 & $\begin{array}{l}\mathrm{Fe}^{4+} / \mathrm{Fe}^{3+} \\
\mathrm{Fe}^{4+} / \mathrm{Fe}^{3+}\end{array}$ & $\begin{array}{l}0.11 \\
0.14\end{array}$ & $\begin{array}{l}0.16 \\
0.67\end{array}$ & $\begin{array}{l}0 \\
0\end{array}$ & $\begin{array}{l}52 \\
48\end{array}$ \\
\hline & 77 & $\begin{array}{l}\mathrm{Fe}^{4+} / \mathrm{Fe}^{3+} \\
\mathrm{Fe}^{4+} / \mathrm{Fe}^{3+} \\
\mathrm{Fe}^{4+} / \mathrm{Fe}^{3+}\end{array}$ & $\begin{array}{l}0.20 \\
0.20 \\
0.20\end{array}$ & $\begin{array}{l}0.00 \\
0.15 \\
0.24\end{array}$ & $\begin{array}{c}0 \\
16.3 \\
28.0\end{array}$ & $\begin{array}{c}36 \\
60 \\
4\end{array}$ \\
\hline \multirow[t]{2}{*}{$\mathrm{La}_{0.1} \mathrm{Sr}_{0.9} \mathrm{Fe}_{0.5} \mathrm{Co}_{0.5} \mathrm{O}_{3-\delta} / \mathrm{F}$} & 300 & $\begin{array}{c}\mathrm{Fe}^{4+} / \mathrm{Fe}^{3+} \\
\mathrm{Fe}^{3+} \\
\mathrm{Fe}^{3+}\end{array}$ & $\begin{array}{l}0.21 \\
0.35 \\
0.36\end{array}$ & $\begin{array}{l}0.40 \\
-0.03 \\
-0.03\end{array}$ & $\begin{array}{c}2.5 \\
51.4 \\
48.3\end{array}$ & $\begin{array}{l}10 \\
59 \\
31\end{array}$ \\
\hline & 77 & $\begin{array}{c}\mathrm{Fe}^{4+} / \mathrm{Fe}^{3+} \\
\mathrm{Fe}^{3+} \\
\mathrm{Fe}^{3+}\end{array}$ & $\begin{array}{l}0.31 \\
0.47 \\
0.45\end{array}$ & $\begin{array}{l}-0.50 \\
-0.06 \\
-0.01\end{array}$ & $\begin{array}{l}12.8 \\
54.9 \\
52.4\end{array}$ & $\begin{array}{l}7 \\
67 \\
26\end{array}$ \\
\hline
\end{tabular}


Fig. 1

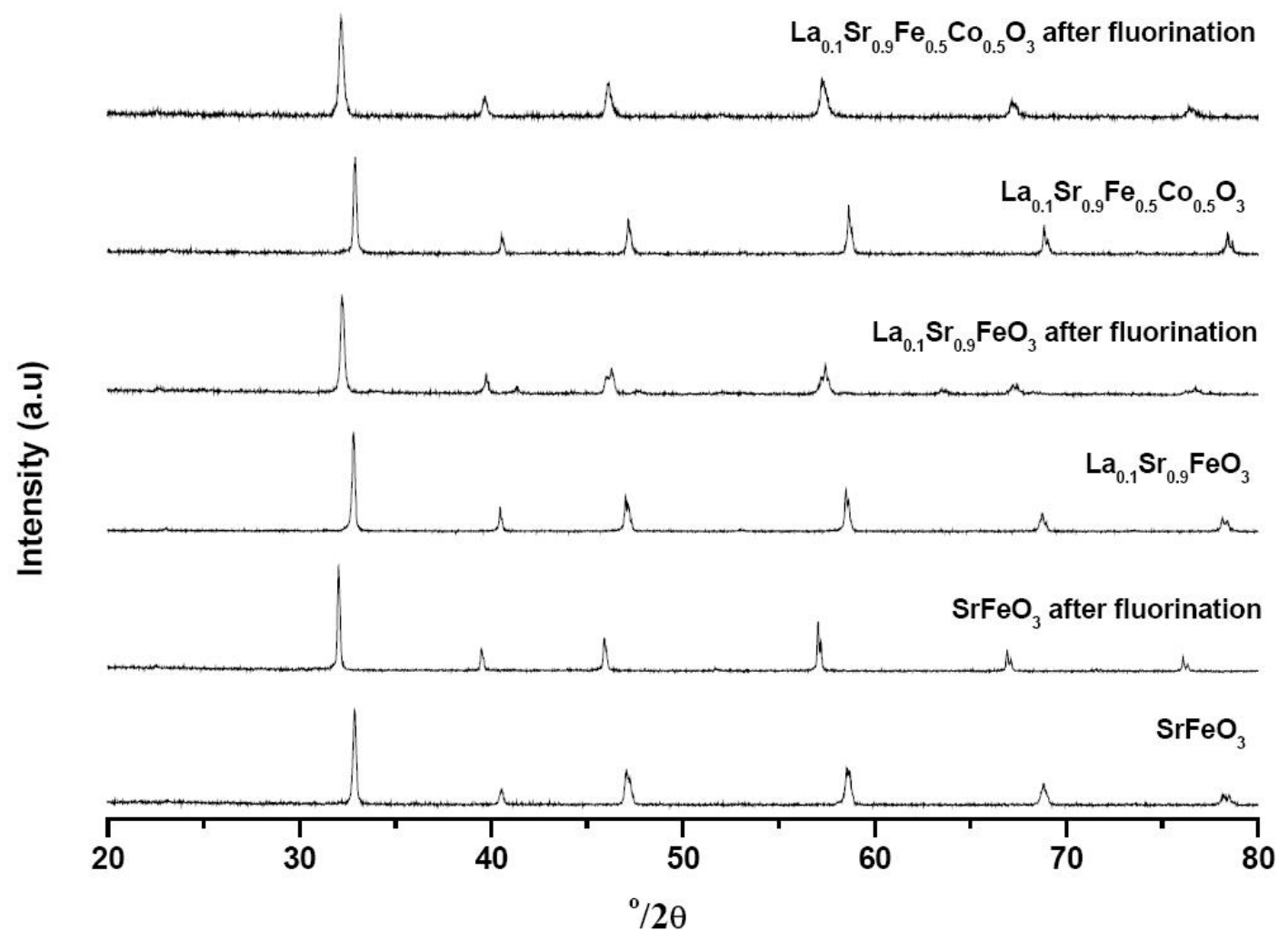


Fig. 2

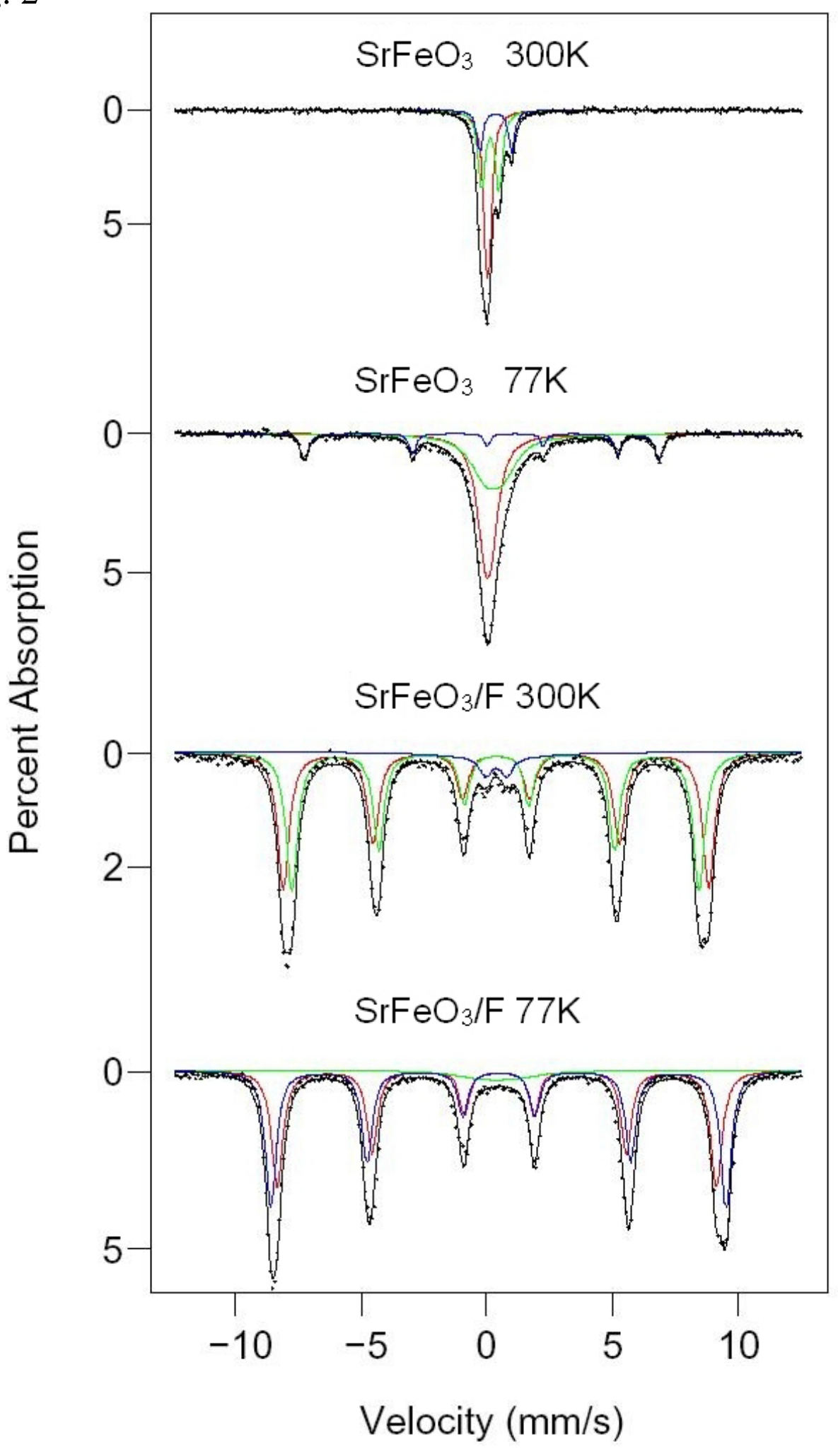


Fig. 3

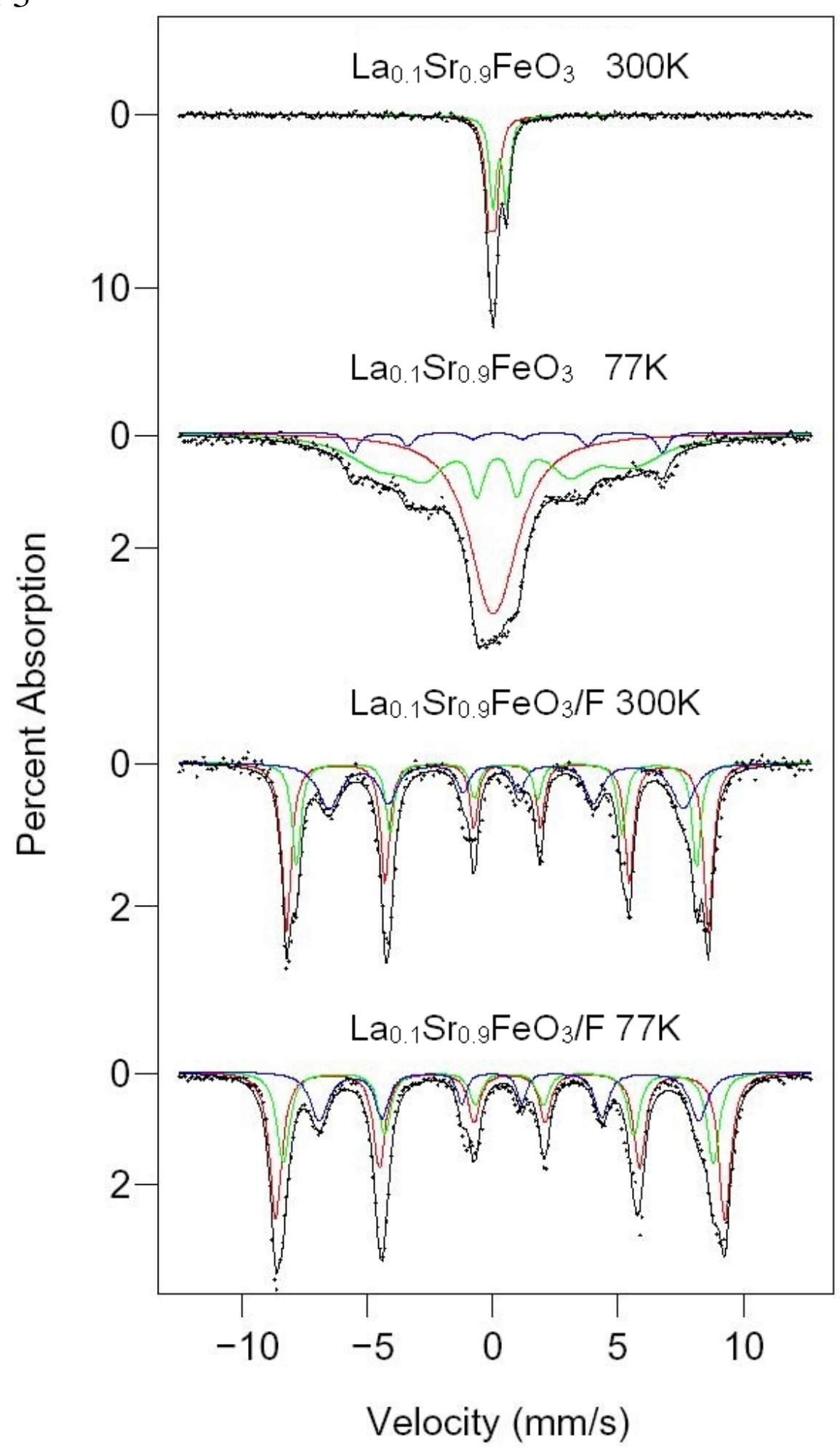


Fig. 4

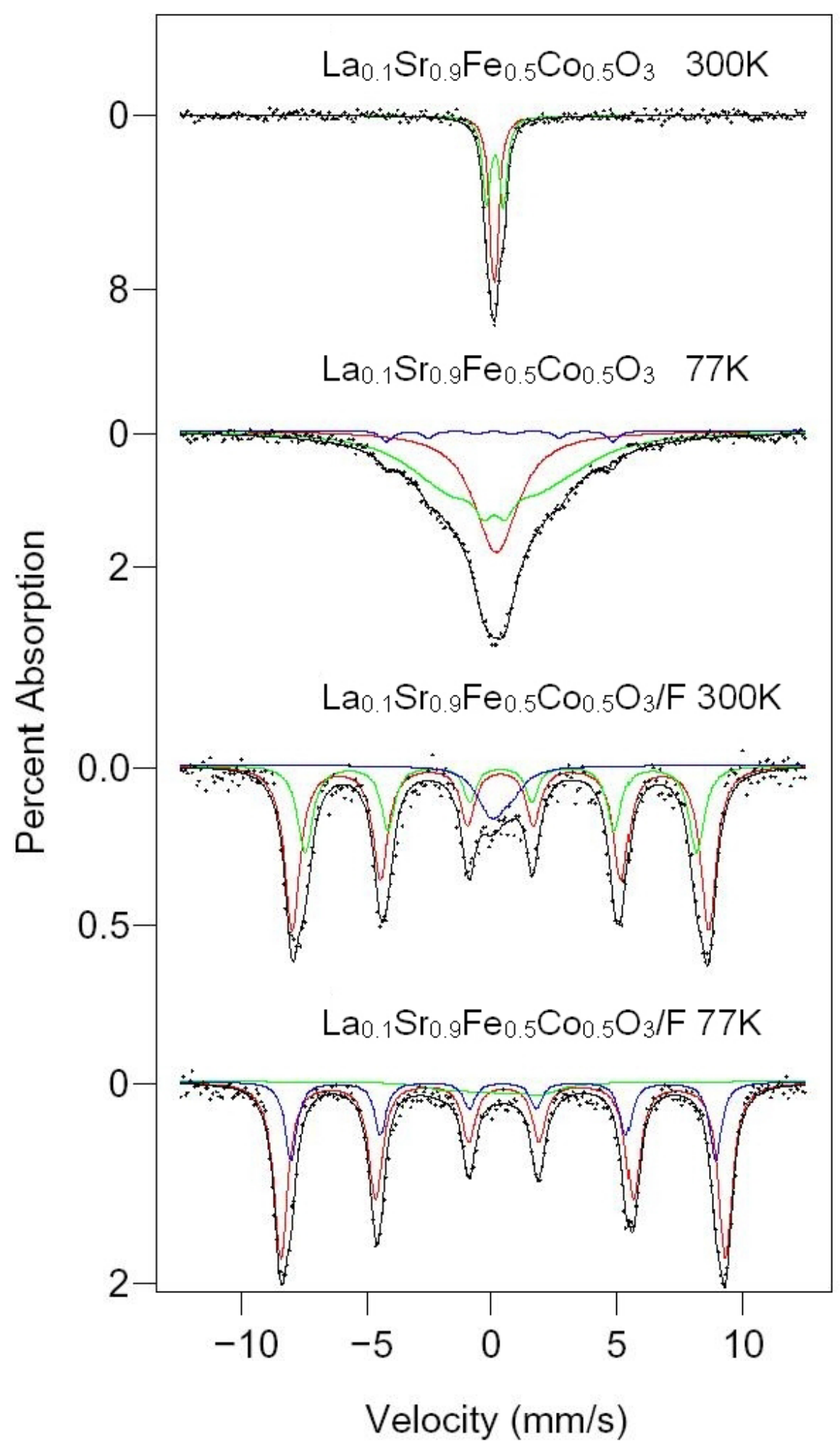

